Bangladesh J. Bot. 47(3): 351-360, 2018 (September)

\title{
SPECIES DIVERSITY, CHANGE IN FOREST COVER AND AREA OF THE SUNDARBANS, BANGLADESH
}

\author{
Ashfaque Ahmed*, Md Ataullah, Parveen Rashid, Ashit Ranjan Paul ${ }^{1}$, \\ Sukumar Dutta ${ }^{2}$ and Mo Shahjahan Ali ${ }^{2}$ \\ Department of Botany, University of Dhaka, Dhaka-1000, Bangladesh
}

Keywords: Species diversity, Invasive species, Forest cover, Forest area, Satellite images

\begin{abstract}
The phytosociological analysis, species diversity and types, fidelity, presence, constancy, Sørensen similarity index and changes in forest cover, land and water areas since 1972 were analyzed. Forty six species were recorded both in quadrats and growing outside which belong to 26 families and 41 genera, 19 were distinguished as true mangrove species and the rest were mangrove associates. Leguminosae and Rhizophoraceae were the dominant families represented by $5 \mathrm{spp}$. each. Three species were found to be invasive, namely Blumea lacera (Burm. F.) DC., Catharanthus roseus (L.) G. Don., Wedelia chinensis (Osbeck) Merr. The maximum importance value index was found in Heritiera fomes Buch.-Ham (48.08). The overall species diversity $(\mathrm{H})$ of SMF was found 3.81, species richness (d) was 9.10 and evenness (e) was 0.47. The forest area was 385,237 ha in 2015. The satellite images showed that the forest and water area of SMF decreased gradually till 2015 in comparison to 1972. The bare land of Sundarbans showed a significantly increasing trend till 2015 since 1972.
\end{abstract}

\section{Introduction}

In the estuary of the River Ganges, in south-west coastal areas of Bangladesh and some part of West Bengal, the Sundarbans Mangrove Forest (SMF) exists. The Sundarbans originally extended about 40 thousand sq. km and forest clearing was initiated by the Turkish Sultans as early as the 13th century for agricultural purposes (Eaton 1991). The forest area reduced to about 20 thousand sq. $\mathrm{km}$ when the British started colonizing the subcontinent in 1793, but the agricultural invasion continued and the forest area reduced by a further $20 \%$ by the 1930s (Blasco 1977). The British Government declared the SMF as a reserve forest under the Forest Act 1927 to halt further encroachment. The Sundarbans is now restricted to around 10 thousand sq. km, stretching between the Baleshwar River, Bangladesh (about 60\%) and the Hooghly River, India (about 40\%).

Due to climate change, sea level rise and other anthropogenic factors the destruction has been aggravated and the area of the SMF drastically reduced over the last few centuries. Therefore, the present research work was undertaken to analyse the current state of the structure, composition, pattern of distribution and the diversity of the mangrove species in the three ecological zones of all four Ranges of SMF and to estimate the changes in forest covers and land area by using satellite images.

\section{Materials and Methods}

Ecological exploration to the SMF of Bangladesh was carried out from 6 to 10 April, 2015. The study was conducted in Chandpai, Sarankhola, Satkhira and Khulna Ranges. Fourteen quadrats were taken in the three ecological zones namely, oligohaline, mesohaline and polyhaline of the SMF (Nazrul-Islam 2003). Details of the sampling stations along with the corresponding co-ordinates

\footnotetext{
*Author for correspondence: <aashfaque67@yahoo.com>. ${ }^{*}$ Deputy Chief Conservator of Forest, Bangladesh Forest Department, Agargaon, Dhaka-1207, Bangladesh. ${ }^{2}$ Bangladesh Space Research and Remote Sensing Organization (SPARRSO), Agargaon, Dhaka-1207, Bangladesh.
} 
have been furnished in Table 1. To find out the total number of different plant species of overall SMF, the plant species situated outside the studied quadrats were also recorded. A $15 \times 15 \mathrm{~m}$ plot (quadrat) was established in each location at about $15-20 \mathrm{~m}$ inland from shore to avoid effects of the nearby flowing rivers (Chen and Twilley 1999) for phytosociological survey. Sampling was done in all the strata i.e. trees, shrubs, herbs and climbers (Table 2). Plants with $\mathrm{dbh} \geq 10 \mathrm{~cm}$ with height at least $8-10$ feet and good growing conditions were considered as tree.

Among the 14 quadrats, 8 were established in oligohaline zone and 3 each in mesohaline and polyhaline zones of the forest (Table 1). The chief synthetic character such as important value index (IVI) was measured according to Curtis (Curtis 1959); the types of species (Tomlinson 1986), fidelity, presence and constancy were measured according to Braun-Blanquet (1932). Species diversity $(\mathrm{H})$ of each site was determined by using Shannon-Weaver Index (Shannon and Weaver 1949), species richness index (d) was calculated according to Margalef (1951), and evenness (e) was calculated according to Pielou (1966). Floristic similarities were measured according to Sørensen (1948) similarities index.

Table 1. Name of the sampling stations in different ecological zones of the Sundarbans mangrove forests along with the co-ordinates and dates of sample collection.

\begin{tabular}{|c|c|c|c|c|c|}
\hline $\begin{array}{l}\text { Location } \\
\text { No. }\end{array}$ & Name of the areas & Co-ordinate & $\begin{array}{l}\text { Ecological } \\
\text { zone }\end{array}$ & Range & $\begin{array}{l}\text { Dates of } \\
\text { sample } \\
\text { collection }\end{array}$ \\
\hline 1 & $\begin{array}{l}\text { Mrigamari (Sela river east } \\
\text { bank) }\end{array}$ & $\begin{array}{l}22^{\circ} 21^{\prime} 36.1^{\prime \prime} \mathrm{N} \\
89^{\circ} 40^{\prime} 8.7^{\prime \prime} \mathrm{E}\end{array}$ & Oligohaline & Chandpai & $\begin{array}{l}06 / 04 / 2015 \\
\text { Quadrat- } 01\end{array}$ \\
\hline 2 & Aandarmanik forest office & $\begin{array}{l}22^{\circ} 21^{\prime} 36.1^{\prime \prime} \mathrm{N} \\
89^{\circ} 40^{\prime} 11.3^{\prime \prime} \mathrm{E}\end{array}$ & $"$ & $"$ & $\begin{array}{l}06 / 04 / 2015 \\
\text { Quadrat-02 }\end{array}$ \\
\hline 3 & Tambulbunia forest office & $\begin{array}{l}22^{\circ} 12^{\prime} 34^{\prime \prime} \mathrm{N} \\
89^{\circ} 41^{\prime} 59.4^{\prime \prime} \mathrm{E}\end{array}$ & $"$ & $"$ & $\begin{array}{l}07 / 04 / 2015 \\
\text { Quadrat-03 }\end{array}$ \\
\hline 4 & Pathuria river west bank & $\begin{array}{l}22^{\circ} 12^{\prime} 33.7^{\prime \prime} \mathrm{N} \\
89^{\circ} 42^{\prime} 16^{\prime \prime} \mathrm{E}\end{array}$ & $"$ & $"$ & $\begin{array}{l}07 / 04 / 2015 \\
\text { Quadrat-04 }\end{array}$ \\
\hline 5 & Pathuria river east bank & $\begin{array}{l}22^{\circ} 12^{\prime} 33.7^{\prime \prime} \mathrm{N} \\
89^{\circ} 42^{\prime} 16^{\prime \prime} \mathrm{E}\end{array}$ & $"$ & Sarankhola & $\begin{array}{l}07 / 04 / 2015 \\
\text { Quadrat-05 }\end{array}$ \\
\hline 6 & Supati forest office & $\begin{array}{l}22^{\circ} 02^{\prime} 51.6^{\prime \prime} \mathrm{N} \\
89^{\circ} 49^{\prime} 41.6^{\prime \prime} \mathrm{E}\end{array}$ & " & $"$ & $\begin{array}{l}07 / 04 / 2015 \\
\text { Quadrat-06 }\end{array}$ \\
\hline 7 & Katka jamtola & $\begin{array}{l}21^{\circ} 51^{\prime} 33.6^{\prime \prime} \mathrm{N} \\
89^{\circ} 46^{\prime} 40.2^{\prime \prime} \mathrm{E}\end{array}$ & Mesohaline & $"$ & $\begin{array}{l}08 / 04 / 2015 \\
\text { Quadrat-07 }\end{array}$ \\
\hline 8 & Katka forest office & $\begin{array}{l}21^{\circ} 51^{\prime} 33.6^{\prime \prime} \mathrm{N} \\
89^{\circ} 46^{\prime} 40.2^{\prime \prime} \mathrm{E}\end{array}$ & $"$ & $"$ & $\begin{array}{l}08 / 04 / 2015 \\
\text { Quadrat-08 }\end{array}$ \\
\hline 9 & Harbaria forest office & $\begin{array}{l}22^{\circ} 15^{\prime} 55^{\prime \prime} \mathrm{N} \\
89^{\circ} 37^{\prime} 5^{\prime \prime} \mathrm{E}\end{array}$ & Oligohaline & Chandpai & $\begin{array}{l}09 / 04 / 2015 \\
\text { Quadrat-09 }\end{array}$ \\
\hline 10 & $\begin{array}{l}\text { Burigoalini forest office } \\
\text { (Opposite site) }\end{array}$ & $\begin{array}{l}22^{\circ} 17^{\prime} 50.5^{\prime \prime} \mathrm{N} \\
89^{\circ} 19^{\prime} 10.9^{\prime \prime} \mathrm{E}\end{array}$ & Polyhaline & Satkhira & $\begin{array}{l}09 / 04 / 2015 \\
\text { Quadrat-10 }\end{array}$ \\
\hline 11 & Kalagachia forest office & $\begin{array}{l}22^{\circ} 12^{\prime} 53.1^{\prime \prime} \mathrm{N} \\
89^{\circ} 14^{\prime} 13.6^{\prime \prime} \mathrm{E}\end{array}$ & $"$ & $"$ & $\begin{array}{l}10 / 04 / 2015 \\
\text { Quadrat-11 }\end{array}$ \\
\hline 12 & Kobadak river west bank & $\begin{array}{l}22^{\circ} 12^{\prime} 53.1^{\prime \prime} \mathrm{N} \\
89^{\circ} 14^{\prime} 13.6^{\prime \prime} \mathrm{E}\end{array}$ & $"$ & $"$ & $\begin{array}{l}10 / 04 / 2015 \\
\text { Quadrat-12 }\end{array}$ \\
\hline 13 & Kashitana forest office & $\begin{array}{l}22^{\circ} 13^{\prime} 17.2^{\prime \prime} \mathrm{N} \\
89^{\circ} 20^{\prime} 53.4^{\prime \prime} \mathrm{E}\end{array}$ & Mesohaline & Khulna & $\begin{array}{l}10 / 04 / 2015 \\
\text { Quadrat-13 }\end{array}$ \\
\hline 14 & Kalabagir tota & $\begin{array}{l}22^{\circ} 24^{\prime} 33.8^{\prime \prime} \mathrm{N} \\
89^{\circ} 27^{\prime} 4.7^{\prime \prime} \mathrm{E}\end{array}$ & Oligohaline & $"$ & $\begin{array}{l}09 / 04 / 2015 \\
\text { Quadrat-14 }\end{array}$ \\
\hline
\end{tabular}


Remote sensing and geographical information system have been applied to assess the changes in the forest cover, water bodies and bare areas. Satellite TM data of 1972, 1989, 2001, 2010 and 2015 were downloaded from GLOVIS, USA. Satellite data were geo-referenced using ERDAS IMAGINE/ ARC-GIS software. Then mosaic was done to the necessary frame and sub-set of Sundarbans forest area for the research work. Fifteen classes were made by unsupervised classification tools of ERDAS IMAGINE software. Finally three classes of areas like forest cover, water bodies and bare land were calculated through the software.

\section{Results and Discussion}

Forty six species was found to be present in the SMF of which 23 were trees, 3 shrubs, 5 herbs and 5 climbers, 2 woody parasites, 3 grasses, 2 palm species and one each of gregarious fern, sedge, prickly screw-pine species. These species belong to 26 families and 41 genera. Leguminosae (5 spp.) and Rhizophoraceae (5 spp.) were the dominant families. Fifteen families were represented by single genus and thus have single species (Table 2). Among 46 species, 32 different plant species were found within the studied quadrats (Table 3 ) and rest 14 species were found outside the quadrats (Table 2).

The flora of the Sundarbans is rich in comparison to most other mangroves in the world and it contains about $44 \%$ of global mangrove species (Alongi 2009). The members of the families Rhizophoraceae and Avicenniaceae generally dominate most of the mangrove forest in the world, while the previous studies indicated that Sundarbans had the greatest abundance of the members of the families Sterculiaceae and Euphorbiaceae (Hussain and Acharya 1994). But in the present study it has been found that Rhizophoraceae and Leguminosae were the dominant. Prain (1903) recorded about 334 plant species, including 35 legumes, 29 grasses, 19 sedges, 18 euphorbia and 50 true mangrove plant species in SMF. Hussain and Acharya (1994) reported 22 families of tree species of which 6 were from Rhizophoraceae, 3 of each from Avicenniaceae and Meliaceae, 2 of each from Combretaceae and Sonneratiaceae from the Sundarbans. Hossain (2003) reported 44 undergrowth species of SMF. Ahmed et al. (2011) recorded only 8 tree species growing in quadrats in their study. Although the mangrove forests of the world is conspicuous for the absence of reproducing under-story herbs and shrubs and for the absence of the vine life form (Janzen 1985), in the present study 3 shrubs and 5 herbs growing in the Sundarbans were recorded.

True mangroves and their associates were differentiated according to Tomlinson (1986). Among 46 species, 19 were distinguished as true mangrove species and rest 27 species were mangrove associates (Table 2). Among 27 mangrove associate species found in the present study, 3 were invasive, namely Blumea lacera (Burm. F.) DC., Catharanthus roseus (L.) G. Don., Wedelia chinensis (Osbeck) Merr. (Table 2). It is considered that invasive species can only spread into natural vegetation as result of disturbance (Biswas 2003). Besides, 25 species of mesophytes were also recorded which were mainly planted by the foresters along the different forest offices of the SMF and one xerophyte, namely Calotropis gigantea $(\mathrm{L}$.) R. Br. and one sand dune species, namely Vitex trifolia L. f. were found to grow naturally west side of Katka forest office. The main mesophytes were Cocus nucifera L., Litchi chinensis Sonn., Mangifera indica L., Artocarpus heterophyllus Lam., Syzygium malaccense (L.) Merr. \& L.M. Perry etc. On the bank of the canals and creeks, Cryptocoryne ciliata (Roxb.) Fisher ex Wydler were also found to grow. One free-floating fern-allies species, namely Salvinia molesta Mitch. was found growing in the drinking water ponds near Tambulbunia and Supoti Forest offices for the first time from SMF which was reported only once from Bangladesh by Hadiuzzaman and Khondker (2005). Banerjee et al. (1989) reported 37 obligate mangroves and 32 mangrove associates from the Indian Sundarbans. 
Table 2. List of plants of SMF of Bangladesh found in and outside the quadrats along with the types of species.

\begin{tabular}{|c|c|c|c|c|c|}
\hline $\begin{array}{l}\text { Sl. } \\
\text { no. }\end{array}$ & Family & $\begin{array}{l}\text { Scientific } \\
\text { name }\end{array}$ & $\begin{array}{l}\text { Ver. } \\
\text { name }\end{array}$ & Habit & Types \\
\hline 1 & Acanthaceae & Acanthus ilicifolius $\mathrm{L}$. & Hargoza & Scrambling herb & MA \\
\hline 2 & Apocynaceae & Catharanthus roseus (L.) G. Don.* & Nayantara & Herb & INV \\
\hline 3 & Apocynaceae & Cerbera odollam Gaertn. & Dhakur & Small tree & MA \\
\hline 4 & Asclcpiadaccae & Sarcolobus globosus Wall. & Bowalilota & Climber & MA \\
\hline 5 & Avicenniaceae & Avicennia marina (Forssk.) Vierh. & Morchabaen & Small tree & $\mathrm{TM}$ \\
\hline 6 & Avicenniaceae & Avicennia officinalis $\underline{\mathrm{L}}$. & Baen & Tree & $\mathrm{TM}$ \\
\hline 7 & Celastraceae & Salacia chinensis L. & Choytbraai & Small tree & MA \\
\hline 8 & Combretaceae & Lumnitzera racemosa Willd. & Kirpa & Small tree & $\mathrm{TM}$ \\
\hline 9 & Compositae & Blumea lacera (Burm.F.) DC. * & Hash & Aromatic herb & INV \\
\hline 10 & Compositae & Wedelia chinensis (Osbeck) Merr.* & Wadella & Herb & INV \\
\hline 11 & Cyperaceae & Cyperus javanicus Houtt. & Kusha & Sedge & MA \\
\hline 12 & Euphorbiaceae & Excoecaria agallocha $\mathrm{L}$. & Gewa & Tree & $\mathrm{TM}$ \\
\hline 13 & Euphorbiaceae & E. indica (Willd.) Muell.-Arg. & Batla & Small tree & $\mathrm{TM}$ \\
\hline 14 & Euphorbiaceae & Shirakiopsis indica (Willd.) Esser.* & Hurmui & Tree & MA \\
\hline 15 & Flagellariaceae & Flagellaria indica $\mathrm{L}$. & Flagellaria & Climber & MA \\
\hline 16 & Gramineae & Imperata cylindrica (L.) Raeusch. & Chhon & Grass & MA \\
\hline 17 & Gramineae & $\begin{array}{l}\text { Myriostachya wightiana (Nees ex } \\
\text { Steud.) Hook.f. }\end{array}$ & Dhanshi & $\begin{array}{l}\text { Grass on } \\
\text { accretions }\end{array}$ & MA \\
\hline 18 & Gramineae & $\begin{array}{l}\text { Phragmites karka (Retz.) Trin. ex } \\
\text { Steud. }\end{array}$ & Nolkhagra & Grass & MA \\
\hline 19 & Leguminosae & Cynometra ramiflora $\mathrm{L}$. & Shingra & Shrub & $\mathrm{TM}$ \\
\hline 20 & Leguminosae & Dalbergia spinosa Roxb. & Chandalota & Shrub & MA \\
\hline 21 & Leguminosae & Derris trifoliate Lour. & Kalilota & Climber & MA \\
\hline 22 & Leguminosae & Mucuna gigantea (Willd.) DC. & Doyal & Climber & MA \\
\hline 23 & Leguminosae & Pongamia pinnata (L.) Pierre. & Karanja & Small tree & MA \\
\hline 24 & Liliaceae & Crinum asiaticum $\mathrm{L}$. & Nagapata & Herb & MA \\
\hline 25 & Loranthaceae & Dendrophthoe pentandra (L.) Miq. & Porgassa & $\begin{array}{l}\text { Woody parasite } \\
\text { on trees }\end{array}$ & MA \\
\hline 26 & Loranthaceae & Viscum monoicum Roxb. ex DC. & Shamulota & $\begin{array}{l}\text { Woody parasite } \\
\text { on trees }\end{array}$ & MA \\
\hline 27 & Malvaceae & Hibiscus tiliaceus L. & Bhola & Shrub & MA \\
\hline 28 & Meliaceae & Aglaia cuculata (Roxb.) Pellegr. & Amur & Small tree & $\mathrm{TM}$ \\
\hline 29 & Meliaceae & Xylocarpus granatum Koen & Dhundul & Small tree & $\mathrm{TM}$ \\
\hline 30 & Meliaceae & X. moluccensis (Lamk.) M. Roem. & Passur & Tree & $\mathrm{TM}$ \\
\hline 31 & Myrsinaceae & Aegiceras corniculata Blanco. & Khalshi & Small tree & $\mathrm{TM}$ \\
\hline 32 & Myrtaceae & Eugenia fruticosa Roxb. & Ban jam & Small tree & MA \\
\hline 33 & Palmae & Nypa fruticans Wurmb. & Golpata & $\begin{array}{l}\text { Palm, under- } \\
\text { ground stem }\end{array}$ & $\mathrm{TM}$ \\
\hline 34 & Palmae & Phoenix paludosa Roxb. & Hantal & Thorn palm & $\mathrm{TM}$ \\
\hline 35 & Pandanaceae & Pandanus foetidus Roxb. & Kewakata & $\begin{array}{l}\text { Prickly } \\
\text { screw-pine }\end{array}$ & MA \\
\hline
\end{tabular}




\begin{tabular}{|c|c|c|c|c|c|}
\hline 36 & Pteridiaceae & Acrostichum aureum $\mathrm{L}$. & Tiger fern & Gregarious fern & MA \\
\hline 37 & Rhizophoraceae & Bruguiera gymnorrhiza (L.) Lamk. & Kankra & Tree & MA \\
\hline 38 & Rhizophoraceae & Ceriops decandra (Griff.) Ding Hou & Goran & Small tree & $\mathrm{TM}$ \\
\hline 39 & Rhizophoraceae & Kandelia candel (L.) Druce. & Gura & Small tree & $\mathrm{TM}$ \\
\hline 40 & Rhizophoraceae & Rhizophora apiculata Blume. & Vora & Tree & $\mathrm{TM}$ \\
\hline 41 & Rhizophoraceae & R. mucronata Poir. & Garjan & $\begin{array}{l}\text { Tree with stilt } \\
\text { roots }\end{array}$ & $\mathrm{TM}$ \\
\hline 42 & Sonneratiaceae & Sonneratia apetala Buch.-Ham. & Keora & Tree & $\mathrm{TM}$ \\
\hline 43 & Sonneratiaceae & S. caseolaris (L.) Engl. & Choyla & Small tree & $\mathrm{TM}$ \\
\hline 44 & Sterculiaceae & Heritiera fomes Buch.-Ham. & Sundri & Tree & $\mathrm{TM}$ \\
\hline 45 & Tamaricaceae & Tamarix dioica Roxb. ex Roth & Jhau & Small tree & MA \\
\hline 46 & Tiliaceae & Brownlowia tersa (L.) Kosterm. & Lotasundry & Climbing shrub & MA \\
\hline
\end{tabular}

(Ver. name $=$ Vernacular name, $\mathrm{TM}=$ True mangroves, $\mathrm{MA}=$ Mangrove associates, $\mathrm{INV}=$ Invasive, $*=$ New found in SMF).

The phytosociological analysis revealed that the maximum IVI in case of overall SMF was found in H. fomes (48.08) (Table 3). Importance value index (IVI) is a measure of how dominant a species in a given forest area and overall picture of ecological importance of the species in relation to the community structure (Curtis and McIntosh 1951). The most dominant species was H. fomes having highest IVI value and then sequentially $S$. apetala and E. agallocha were the other most dominant species in overall SMF. Dominant species were not same within three different ecological zones of SMF. Although $H$. fomes and $S$. apetala were dominant in oligohaline zone, they were not dominant in mesohaline and polyhaline zone. Mesohaline zone was dominated by E. agallocha, $B$. gymnorrhiza and A. marina. On the other hand, polyhaline zone was dominated by A. corniculata and $C$. decandra. The constancy of H. fomes, C. decandra, S. apetala and Xylocarpus moluccensis (Lamk.) M. Roem. was $60-80 \%$ (Class 4) and they were mostly present in studied quadrats in SMF (Table 3). Hibiscus tiliaceus L. was the selective species in SMF (Table 3). The constancy of $E$. agallocha, Phoenix paludosa Roxb., Aglaia cucullata, Avicennia officinalis L. were $40-60 \%$ (Table 3). Nypa fruticans Wurmb. occurred in SMF preferentially (Table 3). The constancy of Acanthus illicifolius L., Acrostichum aureum L., A. corniculata, N. fruticans, Pandanus foetidus Roxb., and Phragmitis karka (Retz.) Trin. Steud. were 20 - 40\%. Acanthus ilicifolius, A. aureum, A. corniculata, A. marina, A. officinalis, Brownlowia tersa (L.) Kosterm., C. decandra, E. agallocha, Rhizophora mucronata Lam., S. apetala and X. moluccensis were in different plants in SMF (Table 3). Aglaia cucullata, B. gymnorrhiza, C. roseus, C. odollam, Cyperus javanicus Houtt., Derris trifoliate Lour., Eugenia fruticosa, L. racemosa, M. gigantea, M. wightiana, P. pinnata, S. indica, Sonneratia caseolaris (L.) Engl. and Tamarix dioica Roxb. ex Roth. were the stranger species and were rarely present in $1-20 \%$ of the sampling units (Table 3). But in some places outside the quadrat specially beside the rivers $P$. pinnata was found to grow profusely. Cynometra ramniflora, $H$. fomes, $P$. foetidus and P. paludosa were the exclusive species of SMF (Table 3). Traditional phytosociology uses the concept of fidelity to recognize character species (Braun-Blanquet 1964), which requires the comparison of constancy values of species among communities. Hibiscus tiliaceus and $N$. fruticans are characteristic species of SMF because of having selective and preferential fidelity, respectively based on Braun-Blanquet (1932).

Species richness is the oldest and the simplest concept of species diversity - the number of species in the community or the region (Krebs 1989). Spatial variability in species diversity was observed within the SMF. Shannon-Weaver Index of diversity showed higher values in oligohaline zone $(H=3.47)$ than in mesohaline $(H=3.11)$ and polyhaline zone $(H=2.77)$ (Table 4$)$. The $\mathrm{H}$-value was relatively lower at polyhaline zone. The both highest and lowest $\mathrm{H}$-values were found 
in two different of quadrats of mesohaline zone where the lowest $\mathrm{H}$-value (1.05) was found in Katka jamtola (Q-7) and highest H-value (2.93) was found in Katka (Q-8). The overall species diversity (H) of SMF was 3.81 (Table 4) indicating in high diversity in terms of species (Barbour et al. 1999).

Table 3. Synthetic characteristics of plant species of SMF in three ecological zones.

\begin{tabular}{|c|c|c|c|c|c|c|c|}
\hline \multirow{2}{*}{$\begin{array}{l}\text { Name of } \\
\text { species }\end{array}$} & \multicolumn{4}{|c|}{ Important value index (IVI) } & \multirow[t]{2}{*}{ Presence } & \multirow[t]{2}{*}{ Fidelity } & \multirow[t]{2}{*}{ Constancy } \\
\hline & Oligohaline & Mesohaline & Polyhaline & Overall & & & \\
\hline Acanthus ilicifolius & 4.75 & 7.84 & 16.49 & 16.36 & Seldom & Indifferents & Class2 \\
\hline Acrostichum aureum & 9.91 & 20.65 & 15.98 & 11.94 & Seldom & Indifferents & Class 2 \\
\hline Aegiceras corniculata & 3.26 & 37.65 & 59.67 & 11.72 & Seldom & Indifferents & Class 2 \\
\hline Aglaia cucullata & 13.37 & 4.96 & - & 10.26 & Often & Strangers & Class 3 \\
\hline Avicennia marina & 2.41 & 36.24 & - & 13.67 & Rare & Indifferents & Class 1 \\
\hline Avicennia officinalis & 8.74 & 5.11 & 11.23 & 8.631 & Often & Indifferents & Class 3 \\
\hline Brownlowia tersa & 6.23 & 11.74 & - & 6.871 & Rare & Indifferents & Class 1 \\
\hline Bruguiera gymnorrhiza & 1.68 & 37.74 & 18.47 & 14.02 & Rare & Strangers & Class 1 \\
\hline Catharanthus roseus & 3.56 & - & - & 1.92 & Rare & Strangers & Class 1 \\
\hline Cerbera odollam & 2.17 & - & - & 1.80 & Rare & Strangers & Class 1 \\
\hline Ceriops decandra & 20.97 & 17.23 & 59.09 & 19.97 & Mostly & Indifferents & Class 4 \\
\hline Cynometra ramiflora & 6.94 & - & - & 2.793 & Rare & Exclusives & Class 1 \\
\hline Cyperus javanicus & 6.82 & - & - & 5.22 & Rare & Strangers & Class 1 \\
\hline Derris trifoliate & 6.52 & - & - & 1.92 & Rare & Strangers & Class 1 \\
\hline Eugenia fruticosa & 3.26 & - & - & 8.924 & Rare & Strangers & Class 1 \\
\hline Excoecaria agallocha & 16.77 & 51.87 & 50.13 & 23.24 & Often & Indifferents & Class 3 \\
\hline Heritiera fomes & 57.05 & 19.27 & 7.66 & 48.08 & Mostly & Exclusives & Class 4 \\
\hline Hibiscus tiliaceus & 6.00 & - & - & 2.793 & Rare & Selectives & Class 1 \\
\hline Lumnizera racemosa & 4.13 & - & - & 1.048 & Rare & Strangers & Class 1 \\
\hline Mucuna gigantea & 2.87 & - & - & 1.048 & Rare & Strangers & Class 1 \\
\hline Myriostachya wightiana & 11.24 & - & - & 1.048 & Rare & Strangers & Class 1 \\
\hline Nypa fruticans & 7.15 & - & 10.34 & 7.565 & Seldom & Preferents & Class 2 \\
\hline Pandanus foetidus & 8.54 & - & - & 6.251 & Seldom & Exclusives & Class 2 \\
\hline Phoenix paludosa & 12.73 & - & - & 10.86 & Often & Exclusives & Class 3 \\
\hline Phragonites karka & 7.94 & - & - & 5.794 & Seldom & Exclusives & Class 2 \\
\hline Pongamia pinnata & 2.41 & - & - & 1.877 & Rare & Strangers & Class 1 \\
\hline Rhizophora mucronata & 3.86 & 4.87 & - & 3.427 & Rare & Indifferents & Class 1 \\
\hline Shirakiopsis indica & 2.87 & - & - & 1.255 & Rare & Strangers & Class 1 \\
\hline Sonneratia apetala & 43.86 & 25.50 & 10.52 & 35.64 & Mostly & Indifferents & Class 4 \\
\hline Sonneratia caseolaris & 4.13 & 5.65 & - & 4.158 & Rare & Strangers & Class 1 \\
\hline Tamarix dioica & 2.17 & - & 26.76 & 3.951 & Rare & Strangers & Class 1 \\
\hline Xylocarpus moluccensis & 7.15 & 11.70 & 11.92 & 17.11 & Mostly & Indifferents & Class 4 \\
\hline
\end{tabular}

IVI, Curtis (1959), fidelity, presences and constancy, Braun-Blanquet (1932), - = Not found.

Species richness $(d)$ were higher in oligohaline zone $(d=10.02)$ than in mesohaline $(d=6.27)$ and polyhaline zone $(\mathrm{d}=4.37)$ (Table 4$)$. The $d$-value was relatively lower at polyhaline zone. The species richness (d) of SMF was 9.10 indicating its peculiarity than any other communities. The lowest d-value was found in Kashitana (1.93) and hightest d-value was found in Aandarmanik (5.99) (Table 4). The overall value of species diversity for the mangroves of Lothian Island, India 
was 2.26 (Joshi and Ghose 2014) and species diversity (2.74) was reported by Nazrul-Islam (1995) for Bangladesh Sundarbans. The present study showed that SMF have higher species diversity.

Table 4. Summary of the species diversity $(\mathrm{H})$, species richness (d), evenness (e) of plant species of overall SMF.

\begin{tabular}{clccc}
\hline Location no. & Area name & $\mathrm{H}$ & $\mathrm{d}$ & $\mathrm{e}$ \\
\hline 1 & Mrigamari (Sela river east bank) & 2.80 & 4.37 & 0.48 \\
2 & Aandarmanik forest office & 2.36 & 5.99 & 0.40 \\
3 & Tambulbunia forest office & 2.65 & 5.81 & 0.55 \\
4 & Pathuria river west bank & 2.52 & 3.88 & 0.42 \\
5 & Pathuria river east bank & 1.91 & 2.79 & 0.38 \\
6 & Supati forest office & 1.20 & 2.71 & 0.20 \\
9 & Harbaria forest office & 2.78 & 4.74 & 0.52 \\
14 & Kalabagirtota & 2.56 & 3.79 & 0.45 \\
Oligohaline zone & & 3.47 & 10.02 & 0.52 \\
7 & Katka jamtola & 1.05 & 2.21 & 0.02 \\
8 & Katka forest office & 2.93 & 4.04 & 0.57 \\
13 & Kashitana forest office & 2.10 & 1.93 & 0.35 \\
Mesohaline zone & & 3.11 & 6.27 & 0.47 \\
10 & Burigoalini forest office (Opposite site) & 1.99 & 3.32 & 0.35 \\
11 & Kalagachia forest office & 1.94 & 2.52 & 0.42 \\
12 & Kobadak river west bank & 2.24 & 3.01 & 0.41 \\
Polyhaline zone & & 2.77 & 4.37 & 0.43 \\
Overall SMF & & 3.81 & 9.10 & 0.47 \\
\hline
\end{tabular}

Since heterogeneity contains two separate ideas - species richness and evenness it was only natural to try to measure the evenness component separately (Krebs 1989). Evenness (e) showed higher values in oligohaline zone $(e=0.52)$ than in mesohaline zone $(e=0.47)$ and polyhaline zone $(\mathrm{e}=0.43)$. The e-value was relatively lower at polyhaline zone. The overall e-value of SMF was 0.47 (Table 4). The lowest e-value (0.02) was found in Kotka jamtola, and highest e-value (0.57) was found in Kotka forest office nearby area (Table 4). The overall evenness of SMF was 0.47. Joshi and Ghose (2014) have found the overall value of evenness for the mangroves of Lothian Island to be 0.52 . Slightly higher evenness (0.82) was reported by Nazrul-Islam (1995) for the mangroves of the Bangladesh Sundarbans.

A good number of stocking rates (plants of $\mathrm{dbh} \geq 10 \mathrm{~cm}$ with height at least $8-10$ feet) of different major mangrove species of SMF was found. Heritiera fomes has growing stocks of 3433 ind./ha and 652 ind./ha in oligo-, and mesohaline zones, respectively. Although no H. fomes was found to grow within the quadrats of polyhaline zone, there were some plants growing in different places of this zone showing very stunted growth (10 - 15 feet only). The overall stocking rate of this plant in SMF was 2012 ind./ha. S. apetala and A. cuculata showed same distribution pattern as H. fomes with overall stocking rate of 1565 and 270 ind./ha, respectively. The growing stock of C. decandra were 925, 534, 2207 and 1117 ind./ha in oligo-, meso-, polyhaline zones and overall SMF, respectively. The number of individuals per ha of E. agallocha in oligo-, meso-, polyhaline zones and overall SMF were 634, 274, 1822 and 1340 ind./ha, respectively. The number of individuals per ha of A. corniculata in oligo-, meso-, polyhaline zones and overall SMF varied from 
634, 274, 1822 and 1340 ind./ha, respectively. Chaffey et al. (1985) showed a decrease in growing stock of plants (plants with $15 \mathrm{~cm} \mathrm{dbh}$ ) with 180 per ha by 1983 in comparison to 296 per ha in 1959 (FORESTAL 1960). Bangladesh forest department recorded a stock of 144 i.e. a further reduction by 48.65\% in 1996 (Aziz and Paul 2015) who reported that (using "Table curve 2D" program) total number of plants would be reduced to 109 per ha in 2020 and number of H. fomes and E. agallocha will be 80 and 7. Ahmed et al. (2011) have shown the reduction of $\mathrm{H}$. fomes by $28.75 \%$ area coverage but an increase in E. agallocha by $6.7 \%$ i.e. 1016 ha between 1989 and 2010 in only two Ranges. The present study does not agree with the findings of Aziz and Paul (2015) and showed a great variation where the number of E. agallocha per ha showed a sharp increase. However, it is in agreement with the findings of Ahmed et al. (2011) who have reported an increase of area coverage of this plant by $6.7 \%$. The increase in the number might be due to the ban on collection of timber of this plant as it was done previously for the raw materials of Khulna News Paper Mills.

The floristic similarities between the 14 locations were examined based on the species presence/absence data using the Sørensen similarity index $\left(\mathrm{C}_{\mathrm{s}}\right)$ (Table 5). According to Sørensen (1948), $C_{s}$ value indicates similarity in floristic composition between two locations. When $C_{s}$ value is greater than 0.5 , it is considered that high similarity in floristic composition present between the locations. The highest $\mathrm{C}_{\mathrm{s}}$ value (0.833) was found between Pathuria river west bank (L-4) and Pathuria river east bank (L-5) of oligohaline zone of SMF (Table 5). The lowest $C_{s}$ was observed between Pathuria river banks (L-4, 5) of oligohaline zone and Kashitana (L-13) of mesohaline zone of SMF (Table 5). In spite of establishing in different ecological zones the following locations showed higher $\mathrm{C}_{\mathrm{s}}$ value between them: Aandarmanik and Katka $8\left(\mathrm{C}_{\mathrm{s}}=0.666\right)$, Pathuria river east bank and Katka jamtola $\left(C_{s}=0.666\right)$ and Katka jamtola location and Burigoalini $\left(C_{s}=0.714\right)$.

Table 5. Sørensen similarity index $\left(C_{s}\right)$ of the 14 locations of SMF.

\begin{tabular}{cccccccccccccc}
\hline $\begin{array}{c}\text { Location } \\
\text { no. }\end{array}$ & 1 & 2 & 3 & 4 & 5 & 6 & 7 & 8 & 9 & 10 & 11 & 12 & 13 \\
\hline 2 & 0.625 & & & & & & & & & & & & \\
3 & 0.222 & 0.500 & & & & & & & & & & & \\
4 & 0.266 & 0.769 & 0.533 & & & & & & & & & & \\
5 & 0.400 & 0.615 & 0.533 & 0.833 & & & & & & & & & \\
6 & 0.375 & 0.285 & 0.250 & 0.307 & 0.461 & & & & & & & & \\
7 & 0.400 & 0.615 & 0.533 & 0.500 & 0.666 & 0.307 & & & & & & & \\
8 & 0.521 & 0.666 & 0.588 & 0.428 & 0.571 & 0.533 & 0.428 & & & & & & \\
9 & 0.631 & 0.705 & 0.315 & 0.500 & 0.500 & 0.235 & 0.500 & 0.555 & & & & & \\
10 & 0.352 & 0.533 & 0.470 & 0.428 & 0.428 & 0.266 & 0.714 & 0.500 & 0.444 & & & & \\
11 & 0.266 & 0.307 & 0.266 & 0.166 & 0.166 & 0.307 & 0.333 & 0.285 & 0.125 & 0.470 & & & \\
12 & 0.222 & 0.250 & 0.333 & 0.133 & 0.307 & 0.250 & 0.307 & 0.352 & 0.526 & 0.533 & 0.400 & & \\
13 & 0.266 & 0.307 & 0.133 & 0 & 0 & 0.153 & 0.333 & 0.428 & 0.250 & 0.545 & 0.333 & 0.400 & \\
14 & 0.352 & 0.307 & 0.250 & 0.428 & 0.266 & 0.333 & 0.285 & 0.125 & 0.470 & 0235 & 0.500 & 0.428 & 0.461 \\
\hline
\end{tabular}

The SMF showed a fluctuation in land area covers. In 1972, the forest area of Sundarbans occupied 398,278 ha (Table 6). But it had been increased 1.52\% in 1989 covering 404,351 ha (Table 6). There had been decreasing tendency of the forest area since then. In 2015, Sundarbans covered 385,237 ha forest area, which was 3.27\% less than that of 1972 (Table 6). The forest area of Sundarbans occupied 398,278 ha in 1972 and 392,398 ha in 2010. There had been a decreasing tendency of the forest area since 1972, which reduced to 385, 237 ha in 2015 i.e. $3.27 \%$ less than that of 1972. This reduction might be due to natural calamities such as Cyclone of 1991, Sidr (2007) 
and Aila (2009), and soil erosion which have destructed the mangroves of Bangladesh during this period. Giri et al. (2014) have shown that the forest lands had an overall increase of $1.4 \%$ during 1970s to 2000s but a decrease of $2.5 \%$ between 1900s and 2000s. Ahmed et al. (2011) reported an overall reduction of total areas of the two Ranges (Chandpai and Khulna) by 3.6\% (1598 ha) of Bangladesh SMF. The water area of Sundarbans which was 224,109 ha in 1972 (Table 6) decreased gradually in comparison to 1972 . The bare land of Sundarbans showed a significantly increase trend till 2015 since 1972. But it decreased in 2010 having 9,100 ha than 2001. Sundarbans had 17,312 ha land area in 2015, which increased greatly $12655.67 \%$ than 1972.

Table 6. Changes of forest cover (ha), water area and bare land from 1972 to 2015 of SMF, determined by GIS technique (unsupervised classification of Satellite TM data).

\begin{tabular}{cccccccc}
\hline $\begin{array}{c}\text { Serial } \\
\text { No. }\end{array}$ & Year & $\begin{array}{c}\text { Forest } \\
\text { area (ha) }\end{array}$ & $\begin{array}{c}\% \text { area } \\
\text { increased or } \\
\text { decreased } \\
\text { (since 1972) }\end{array}$ & $\begin{array}{c}\text { Water } \\
\text { area (ha) }\end{array}$ & $\begin{array}{c}\% \text { area } \\
\text { increased or } \\
\text { decreased } \\
\text { (since 1972) }\end{array}$ & $\begin{array}{c}\text { Bare area } \\
\text { (ha) }\end{array}$ & $\begin{array}{c}\% \text { area } \\
\text { increased or } \\
\text { decreased } \\
\text { (since 1972) }\end{array}$ \\
\hline 1. & 1972 & $3,98,278$ & - & $2,24,109$ & - & 135.72 & - \\
2. & 1989 & $4,04,351$ & $1.52 \%$ & $2,15,000$ & $-4.06 \%$ & $2,676.15$ & $1871.82 \%$ \\
3. & 2001 & $3,87,555$ & $-2.69 \%$ & $2,29,234$ & $-2.29 \%$ & $13,521.10$ & $9862.49 \%$ \\
4. & 2010 & $3,92,398$ & $-1.48 \%$ & $2,20,530$ & $-1.60 \%$ & $9,100.00$ & $6604.98 \%$ \\
5. & 2015 & $3,85,237$ & $-3.27 \%$ & $2,19,201$ & $-2.19 \%$ & $17,312.00$ & $12655.67 \%$ \\
\hline
\end{tabular}

The present study provides an update of the state of plant diversity and changes in forest cover and area and is likely to contribute in assessing the different anthropogenic impacts. Therefore, the SMF being World Heritage deserves special attention particularly from the Government of the People's Republics of Bangladesh for its conservation.

\section{Acknowledgements}

The authors are grateful to the Ministry of Science and Technology, Government of People's Republic of Bangladesh for providing partial support to carry out the work through a project to the corresponding author. They are grateful to the Department of Forests for allowing them to visit the forests, to Professor Dr. Mohammad Nurul Islam, Mr. Md. Musfiqur Rahman Chowdhury, Ms. Sharmin Hasan, Mr. Md. Mohsin Akbar, Mr. Muminur Rashid for their support during field visit.

\section{References}

Ahmed A, Aziz A, Khan AZMNA, Islam MN, Iqubal KF, Nazma and Islam MS 2011. Tree diversity as affected by salinity in the Sundarbans Mangrove Forests, Bangladesh. Bangladesh J. Bot. 40(2): 197-202.

Alongi DM 2009. The Energetics of Mangrove Forest. Springer, Netherlands.

Aziz A and Paul AR 2015. Bangladesh Sundarbans: Present status of the environment and biota. Diversity 7 : 242-269.

Banerjee LK, Sastry ARK and Nayar MP 1989. Mangroves in India, Identification Manual. Botanical Survey of India, Kolkata.

Barbour M, Burk JH, Pitts WD, Gillians FS and Schwartz MW 1999. Terrestrial Ecology. Addson Wesley Longman, Inc Illinois, Chicago.

Biswas SR 2003. Invasive plants of Sundarbans. In: Interim report under SBCP project, IUCN, Bangladesh. pp. 34. 
Blasco F 1977. Outlines of ecology, botany and forestry of the mangals of the Indian subcontinent. In: Wet Coastal Ecosystems. Chapman VJ (Eds.). Elsevier, Amsterdam. pp. 241-260.

Braun-Blanquet J 1932. Plant sociology: The study of plant communities. Hafner, London.

Braun-Blanquet J 1964. Pflanzensoziologie - Grundzu“ge der Vegetationskunde. 3rd ed. Springer, Vienna, AT.

Chaffey DR, Miller FR and Sandom JH 1985. A forest inventory of the Sundarbans, Bangladesh: Main report, Project report 140. Surrey, Overseas Development Administration, Land Resources Development Centre.

Chen R and Twilley RR 1999. Patterns of mangrove forest structure and soil nutrient dynamics along the Shark river estuary, Florida. Estuaries 22: 955-970.

Curtis JT 1959. The vegetation of Wisconsin: An ordination of plant communities. University of Wisconsin Press, Madison.

Curtis JT and Mclntosh RP 1951. An upland forest continuum in the prairie forest border region of Wisconsin. Ecology 32: 476-496.

Eaton R 1991. Human Settlement and Colonization in the Sundarbans, 1200-1750. In: Seidensticker J, Kurin R and Townsend AK (Eds.). The commons in South Asia: Societal pressure and environmental integrity in the Sundarbans. The International Centre, Smithsonian Institution, Washington DC.

FORESTAL (Forestry and Engineering International Ltd.) 1960. Forest Inventory 1958 - 59 Sundarbans Forests FORESTAL: Vancouver, BC, Canada.

Giri C, Long J, Abbas S, Murali RM, Qamer FM, Pengra B and Thau D 2014. Distribution and dynamics of mangrove forests of south Asia. J. Environ. Manag. 100: 1-11.

Hadiuzzaman S and Khondker M 2005. Salvinia molesta Mitch. (Salviniaceae)- A free floating fern-allies new to Bangladesh. Bangladesh J. Bot. 34(1): 37-39.

Hossain ABME 2003. The undergrowth species of Sundarban mangrove forest ecosystem (Bangladesh). The final report on Sundarban Biodiversity Conservation Project, IUCN, Dhaka, Bangladesh.

Hussain Z and Acharya G 1994. Mangroves of the Sundarbans. Volume two: Bangladesh. IUCN, Bangkok, Thailand pp. 256.

Janzen DH 1985. Mangroves: Where's the understory? J. Trop. Ecol. 1: 89-92.

Joshi HG and Ghose M 2014. Community structure, species diversity, and above ground biomass of the Sundarbans mangrove swamps. J. Trop. Ecol. 55(3): 283-303.

Krebs CJ 1989. Ecological methodology. Harper Collins, N. Y. pp 620.

Margalef R 1951. Species diversity in natural comunidales. Publ. Inst. Biol. Apl. 9: 5-27.

Nazrul-Islam AKM 1995. Ecological conditions and species diversity in Sundarbans mangrove forest community, Bangladesh. pp. 294-305. In: Khan MA and Unger IA (Eds.) Biology of Salt Tolerant Plants. Book Grafters, Michigan, USA.

Nazrul-Islam AKM 2003. Mangrove forest ecology of Sundarbans: The study of change in water, soil and plant diversity. In: Sustainable Environment: A Statistical Analysis, Ghosh AK, Ghosh JK, Mukhopadhaya MK (Eds.). Oxford University Press: New Delhi, India. pp. 126-147.

Pielou EC 1966. The measurement of diversity in different types of biological collections. J. Theo. Biol. 13: $131-144$

Prain O 1903. The flora of Sundarbans. Records of the Botanical Survey of India. Delhi-231-370.

Shannon CE and Weaver W 1949. The mathematical theory of communication. Univ. Illinois Press, Illinois. p. 125.

Sørensen TA 1948. A method of establishing groups of equal amplitude in plant sociology based on similarity of species content, and its application to analyses of the vegetation on Danish commons. Kgl. Danske Vidensk. Selsk. Biol. Skr. 5: 1-34.

Tomlinson PB 1986. The Botany of Mangroves. Cambridge University Press, Cambridge. U.K. pp. 404. 